\title{
The Global Currency Area a Way to Constructively End the Era of Reserve Currency
}

\author{
Mieczysław Dobija \\ Faculty of Management, Cracow University of Economics, Cracow, Poland \\ Email: dobijam@uek.krakow.pl
}

Received 12 February 2014; revised 12 March 2014; accepted 19 March 2014

Copyright (C) 2014 by author and Scientific Research Publishing Inc. This work is licensed under the Creative Commons Attribution International License (CC BY). http://creativecommons.org/licenses/by/4.0/ c) (i) Open Access

\begin{abstract}
An integrative currency area that is able to unify countries with different levels of labor productivity leads to a global currency area with only one currency. In such a scenario, the reserve money system would obviously disappear. This concept, linked with the correct view that money is a receivable for labor done, offers a new vision of globalization. This paper considers the necessary fundamentals of a global currency area and a post-exchange rate world economy. The study explores a new financial framework as well as the significance of the labor productivity ratio in macroeconomic control.
\end{abstract}

\section{Keywords}

Integrative Currency Area, Global Currency Area, Reserve Money System, Self-Financing, The Equation of Exchange, Labor Productivity Index

\section{Introduction}

The formation of a global currency area (GCA) would signal the natural end of the reserve currency system. Then, only one money unit would rule globally without any exchange rate. Accordingly, reserve money as well as an exchange rate theory would no longer be required as a firm and indispensable part of economics. This paper presents ways to solve the host of problems on the path to one world currency. This paper's aim is to explain the fundamentals required for the formation of a GCA and suggest that overcoming the present dilemmas of a global reserve system, as discussed by J. Stiglitz [1] and others, is possible. Cost benefits analysis also shows that a political motivation can appear too, so that a GCA is within our reach.

Progress in forming the GCA is achievable under one main condition; namely, reshaping the central banks in 
all the world's states to institutions whose foremost duty is to pay remunerations to public sector employees (PSE). The second important duty is tight control over the labor productivity of each member of the GCA. Of course, an emission of cash money would no longer exist, nor would it be acceptable. Thus, the introduction of the GCA would also signal the end of the paper (cash) money era. These principal changes of the central bank's functions, and forbidding money emissions, would bring economics to the world of sciences, according to the conditions listed in [2] [3]. Economics would become a science in view of the fact that the fundamental laws of reality would no longer be omitted or respected. Like energy, capital does not arise from nothing. Despite this firm fact, the present central banks (and semi institutions) act as if the fundamental law of conservation does not concern them. As a result, the emissions of cash money introduced to the economy produce most economic troubles in the form of unemployment, inflation, and a constant lack of positive solutions to burgeoning economic problems. In addition, the present central banks' activities have turned stock exchanges into mechanisms for evaporating investment value in sudden crises or in a slow process of inflation.

Here it is worth noting that the creation and development of the GCA are not equivalent to global freedom of movement for the population. The GCA is a way to strive for a welfare state, which can be achieved by wise, hardy, and productive labor with the help of an encouraging international environment. But the states would have to enter onto the path of real growth using their own resources (material and human) and accessible intellectual capital. The GCA would be free from exchange rates and all the intellectual challenges related to them, such as accompanying risk and exchange rate policy. Having the GCA working, the exchange rate would not disturb the value of products or the world's economic statistics. This end of the reserve currency system could be viewed as a happy event or process, since each owner of the money held as a reserve could use this money in the entire GCA. Therefore, the issuer of the world's reserve money would not be alarmed when a river of banknotes returned to the source of their emission.

Here a note is necessary. Most economists appear not to know that it is a category of labor that transfers capital to products, and this process concentrates on this capital, which increases the value of these products. These transfers come from the source of capital, that is to say the human capital of employees or capital embodied in the assets. This is the reason why the inflows of capital to the economy and all flows inside the economy are not sufficiently recognized. In particular, an inflow of capital to the economy through labor accomplished by the PSE is ignored as if it does not exist or is valueless. Therefore, in the present system, these employees are paid from tax funds instead of direct payment equivalent to the value of the accomplished work. This is the reason for taxes that are too high, budget deficits, lack of demand, and partial unemployment. In a well-ordered economy this would lead to nasty deflation since inflow of capital transferred by labor in the public sector is not equalized by the flow of remuneration. This is one reason highly developed countries also have high budget deficits, and it is the reason why J. Stiglitz [4] has warned of a sudden constraint.

In the present situation, the error of relying on financing public sector compensation from tax funds is to some extent set off by the emission of cash money. These two actions have some opposite influences; nevertheless, they are both wrong. The central bank's change to payer for the labor done in the public sector will establish the correct order. Then compensations of the PSE, paid as if "from nothing" by the central bank, will, in fact, be equal to the value transferred by the labor of these employees. Then the inflow to the economy of value concentrated in products equivalently confronts the stream of money that is correctly determined. Thus, in scientific economics, the central bank is the payer of the PSE and this bank no longer creates cash money from nothing. The category of cash money disappears completely, although banknotes can be left for a time.

This paper [5] [6] describes the creation of an integrative currency area as a concept that is opposite to a discriminative one, organized under conditions of an optimal currency area theory. The integrative area is able to incorporate each country, no matter what the level of their economic development is. Here is a continuation, but considerations are focused on the formation of the GCA and the economics after abolishing the reserve currency system. The beginning reverts to a category of capital and labor as theoretical fundamentals.

\section{Interpretation of Capital, Labor, and Accounting Identity}

In 1494 a famous book was published in Venice called the Summa. This printed book by Luca Pacioli [7] consisted, among others, of a description of double-entry accounting. The description begins with accounting identity, which shows that at moment zero:

$$
\text { Assets }=\text { Liabilities (Debts) }+ \text { Equitycapital(Equity) }
$$


This is the usual beginning of basic accounting lectures, but beyond all the teaching agendas, this identity hides a way to figure out what capital is. A direct result of this identity is that capital is an abstract category, albeit most important. In addition, capital is a measurable category and its concentration in an asset is the reason for this asset value.

In contrast to this natural report, after ages of studies, economists have concluded a lack of understanding of capital matters. This was clearly expressed by Ch. Bliss [8]. In 1975, this author wrote that: “(...) When economists reach agreement on the theory of capital they will shortly reach agreement on everything. Happily, for those who enjoy a diversity of views and beliefs, there is very little danger of this outcome. Indeed, there is at present not even agreement as to what the subject is about (...)". Let us remind scholars that, among others, there is the well-known "Cambridge controversy" [9], of which an essential aspect is understanding capital. It is true that many economists have attempted to explain this notion. For example, R. Solow [10] wrote: “...It seems that some of the same questions that were debated in the 19th century, for example, how should 'capital' be measured, remain matters of contention today. I speak diffidently about this because I find the earlier discussions terribly confusing and occasionally incomprehensible to a contemporary economist. Indeed, I suppose I should confess I sometimes feel much the same way about the current discussion even though - even when-I take part in it myself. This is a matter of some significance, because when a theoretical question remains debatable after 80 years there is a presumption that the question is badly posed - or very deep indeed. I believe that the question of the measurement of 'capital' is badly posed, and I hope I can bring you around to my point of view..."

The abstract nature of capital has already been explained by M. Dobija [11] and B. Kurek [2] [12]. The authors interpret capital as the abstract ability of doing work. What is more, an economic constant of potential growth is discovered. This constant allows for the formulation of a model of capital growth and an explanation of the nature of income. There are two great domains where the abstract ability of performing work is of the greatest importance. As P. Atkins [13] explains, it is physics where the ability of doing work (energy) is a core notion. Similarly, it is economics where capital is a basic category [14]. Therefore, we can better understand relationships between human capital and labor. It does not mean a direct and intellectually fruitless bringing of physics theories to economics. Such a procedure usually does not yield good issues, because of the fundamental separation of research subjects and the domains of physics and economics. Conversely, the fundamental laws of conservation have to be respected everywhere, including economics. Labor by nature is a transfer; the transfer of energy to the object of work in physics, and it is the transfer of employees' human capital to products in an economy. Therefore, a unit of labor is also a unit of energy; thus, this implies that in an economy, a monetary unit has to be the labor unit as well. It has to be so, since we get money for accomplished work.

A leading scientist, $\mathrm{M}$. Gleiser [15], pointed out that science is a narrative in which the constants of nature are the letters of the alphabet and the fundamental laws are the rules of grammar. That author stressed that in various sciences a researcher has to be aware of the fundamental laws of Nature and the constants that accompany them. The significance of constants has been broadly explained by J. Barrow [16], who noticed that constants define the fabric of the Universe. The values of identified constants are manifestations of reality. For example, a gravitational constant allows for a computation of the Earth's acceleration. By computing this acceleration, engineers can calculate gravitational forces and are able to plan the structure of contemporary buildings. The kernel of science is, therefore, a scientific method that recognizes fundamental principles and constants. The study of capital matters leads to the conclusion that the potential growth of capital invested in economic activities has a potential growth of eight percent. This is an economic constant that discovers the nature of subsistence space. The principle of the exponential growth of capital invested in business activities is the result of an economic constant. If the market did not reward economic agents, nobody would undertake economic activities, as their concentration of capital would deteriorate according to the second principle. The manifestation of the constant can be mathematically described in the form of Equation number (2):

$$
C_{t 1, p}=C_{t 0} \times e^{p \times \Delta t}
$$

where: $C_{t 0}$-the beginning concentration of capital [expressed in monetary terms] in the time moment $t 0, p$ - economic constant of potential growth, $p=E(s)=0.08$ [expressed as $1 /$ year], $C_{t 1, p}$-the ending concentration of capital [expressed in monetary terms] in the time moment $t 1$, which has been subdued to the economic constant of potential growth "p" through the time period $\Delta t, \Delta t$-time period between time moments: $t 0$ and $t 1$ [expressed in years]. 
Additionally, managers of companies may try to limit natural dispersion through labor and good management $M$. That is the third variable that influences the concentration of capital invested in business activities. All these variables taken together describe the ending concentration of capital, which can be mathematically described in the form of Equation number (3):

$$
C_{t 1, s, p, M}=C_{t 0} \times e^{(p-s+M) \times \Delta t} \text { and } p=E(s)=0.08
$$

where: $C_{t 0}$-the beginning concentration of capital [expressed in monetary terms] in the time moment $t 0, C_{t 1}, s, p, M$ - the ending concentration of capital [expressed in monetary terms] in the time moment $t 1$, which has been subdued to natural dispersion "s" (uncertainty), the economic constant of potential growth "p" and a management variable " $\mathrm{M}$ " through the time period $\Delta t, s$-random variable of dispersion (uncertainty) [expressed as 1/year], $p$-economic constant of potential growth, $p=E(s)=0.08$ [expressed as 1/year], $E(s)$ - mean value of $s$, — management variable [expressed as 1 year], $\Delta t$-time period between time moments: $t 0$ and $t 1$ [expressed in years].

In conclusion, the economic constant of potential growth as well as activities of managers (and the whole labor force) are sources of profit, since these two variables positively influence the initial capital invested in business activities. Accounting as an economic discipline measures periodic changes in capital invested in business activities. Those changes are expectantly a profit. These profits correspond to the level of an economic constant of potential growth and to the level of capital involved in business activities, as well as to the manager's skills. Research conducted by B. Kurek [17], who used large sets of data, leads to the conclusion that the annual average value of a ratio of profit to total capital (ROA) is pretty stable and close to eight percent. Therefore, we claim that invested capital grows according to the compound interest formula, which is the essence of the principle of exponential growth. Applying a wider interpretation, we may conclude that the game with Nature is a positive non-zero sum game. Nature enables the growth of capital on a level close to eight percent per year. A significant number of research papers also suggest that the average return on human capital (fair minimum salaries and wages) is close to eight percent per year.

Capital and labor are by definition tightly tied up. They are interdependent categories forming a tandem. Labor is present in the definition of capital and vice versa. Capital is a potential category, whereas labor is a dynamic one. Labor as the transfer of capital has a strong relationship with power (labor $=$ power $\times$ timeoflabor ). The category of power has always been present in economics, since the list of labor positions in a company or institution differs mainly by rate of pay. The pay of an employee divided by the highest pay denotes power indexes assigned to work positions.

These power indexes existed in prehistoric times. V. Struve [18] described ratios applied to workers in the third millennium BC in the Sumerian town-state of Lagasz. “... The igi-gar-ag documents, or control documents, of the gang of workmen (erin), i.e., of the actual number of workmen, were preserved in archives together with documents containing the (assessment of labor force of the gang of workmen), i.e., of the quantity of their man-days. ... In addition to the unit of labor force, the scribes of Ur III distinguished such quantities as 5/6, 2/3, $1 / 2$, etc. of the unit of labor force. The gurus whose productivity of labor was estimated at 5/6, 2/3, 1/2, etc. of a unit of labor force received grain ratios proportionately reduced. ..." Much earlier, when tokens served for counting and accounting, as D. Schmandt-Besserat correctly interprets, a special token shaped as a tetrahedron served as a labor unit (see Figure 1). Apparently, the idea of measuring workers' labor to proportionately compensate them, served humans from the dawn of civilization.

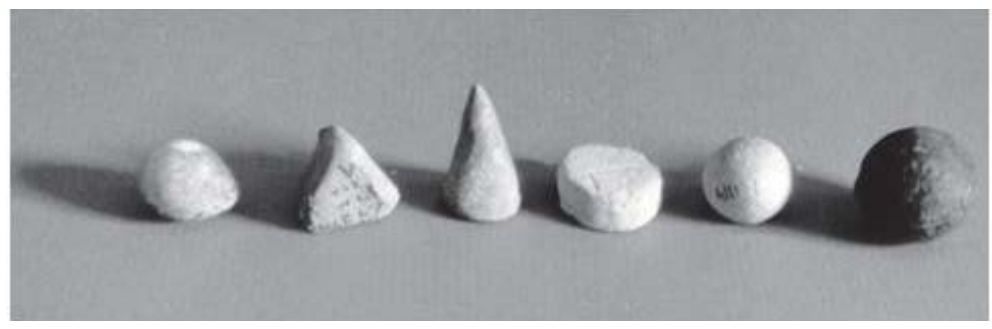

Figure 1. Plain tokens, Mesopotamia, present day Iraq, ca. 4000 BC. The cone, spheres, and disk represented various grain measures; the tetrahedron stood for a unit of labor. Courtesy Denise Schmandt-Besserat [19]. 
Capital and labor originate in natural tandem. Yet in economics, the labor of capital embodied in employees' needs a fair compensation. Hence, labor (or work) receivables appear as an essential category. This is money employees exchange for goods and services, and these processes are the very nature of the money-goods economy. Thus, there is a triad capital-labor-money, which reigns supreme over economics. These considerations lead to an important notion. If labor is the real transfer of capital, and labor receivables are determined by the process of this flow of capital measurement, so money arises as an accounting record of accomplished labor. Consequently, the plausible notion of the self-financing of labor emerges. This is a significant truth for the money-goods economy, since in order to pay compensation for the PSE we do not need taxes but an institution with authorization placing the work receivables into the employees' bank account. This is a premise of central bank reform. On the other hand, creating cash money by the central bank is an activity that goes against the fundamental law of Nature, since capital does not originate from nothing.

\section{Human Capital Measurement Model and Labor Productivity Index}

The model of human capital measurement is derived from the general model of capital growth (1). An infant comes to the world as a gift of Nature, so a value is not assigned to it, similarly to coal or wheat, which gather value by the cost of mining and transport in the case of the coal, or the cost of planting and harvesting in the case of wheat. In the general model of capital are two variables: dispersion (s) and the inflow of capital by labor (M), as well the economic constant (p). In the case of the infant it is obvious the forces represented by (s) would be damaging to the new life; however, the efforts of the parents and society (labor $\mathrm{M}$ ) set off these forces. Thus, it is only the constant (p) that plays a role in human capital development. Therefore, the basic model of human capital measurement, as introduced in [20], is determined by the formula:

$$
H(p, T)=[K(p)+E(p)][1+U(T, w)]
$$

where: $K$-denotes the capitalized value of the cost of living, $E$ - denotes the capitalized value of the cost of professional educations, $p$-capitalization rate $=0.08, U$-sort of learning function with a learning parameter $w$, $T$-number of years of professional occupation.

In the additive form, the above model is equivalent to the form:

$$
H(p, T)=K(p)+E(p)+D(T, w)
$$

where $D(T, w)$ denotes capital gained from job experience. This form of model is convenient for shaping the model of compensation for work.

The fundamental principle of fair compensation is derived from the second law of thermodynamics. Capital embodied in individuals comes under the law of spontaneous and random dispersion(s). Therefore, the minimal annual compensation for employees is determined by the formula $W=s \times H(T, p)$. Since (s) is a random variable with a mean value $E(s)=p$, the formula suitable for wage estimation is

$$
W=p \times H(T, p) .
$$

The above models consist of natural factors as $K(p), E(p), D(T, w)$. One more part of human capital exists, namely creativity capital. One can agree that $\mathrm{N}$. Tesla's inventions, as well as many great inventors and scientists, had special sources for their outstanding creativity; these sources lay beyond education and experiences. Therefore, it is right to add one more factor to the model, namely creativity capital. Then the additive model of human capital comprises four elements:

$$
H(T, p)=K(p)+E(p)+D(T, w)+C_{r}
$$

where $C_{r}$ denotes creativity capital.

Solving the IRR Equation written for human capital we get confirmation that regular compensation is a percentage of $H(T, p)$ The IRR Equation for one year is as follows:

$$
H(T, p)(1+r)=W+H(T+1, p)
$$

Solution of the Equation (8) is: 


$$
W=r \times H(T, p)-\Delta D(T, w)
$$

The factor $\Delta D(T, w)$ denotes increased experience during the last year of employment. The formula (9) shows that experience gained in the former year belongs to the company that created the place of the job. The factor $\Delta D(T, w)$ tends quickly to zero, when $T$ grows. Therefore the general formula of pay is $W=r \times H(T, p)$. If $r=p$ it is the fair minimum pay. Research [21] shows that the average value of $r=10 \%$ in a good working company. This means that to the basic pay (8\%) is added c. $25 \%$ of a bonus pay.

The theory of human capital measurement introduced above leads to the opinion that basic pay (L), determined as $8 \%$ of an employee's human capital, is a fair minimum pay. This means this level of pay allows for the preservation of the employee's human capital. This opinion is confirmed by the fact that the present value of such a stream of pays is not less than the initial human capital, so this capital is preserved. If basic pay is $L=p H(T m, p) s o P V \infty=p H(T m, p) / s$, where (s) is the ratio of dispersion (formula 2), and (m) is the chosen year of employment, and $H(T m, p)$ for years: $m+2, m+2 \cdots$ is constant. If the random variable s is replaced by the mean value $p=E(s)$, then $P V \infty=p H(T, p) / p=H(T, p)$. This proves that the stream of wages is equal to $H(T, p)$ so the human capital is preserved.

\section{Money-Goods Economy. A Modern Financial Framework}

An indispensable condition of accessing the integrative currency area is the mentioned reshaping of the central bank to the institution endorsed as the only legal payer of compensation to the PSE employees. Then an index of labor productivity Q is easily calculated. This index is defined as a quotient of GDP and total compensations $W$, so $Q=G D P / W$. At the new framework, the $\mathrm{Q}$ can be simply computed since financing the PSA from funds collected by taxes no longer exists. Employees did not pay any more taxes for the earnings of other employees, which perturbs the computation of the $\mathrm{Q}$. This is significant since the $\mathrm{Q}$ plays an extremely important role in the control of an economy. First, the Q participates in the wage Equation of exchange goods for money, and vice versa.

The introduction of labor self-financing causes the financial framework of the money-goods economy to look like Scheme 1. In the upper part of this scheme runs the stream of products and services value. This stream confronts the parallel stream of money that starts as employees' compensations. Both streams end on markets where money is exchanged for the value of goods and services. The confrontation discloses also the purchasing power of money.

The box placed on the right side includes the idea of the Equation of exchange, that is to say, the exchange of goods and services on money. The value that has flowed on the market for a period of a year is simply GDP. The stream of money divides into two sub streams; the first (aW) flows directly to the market, since earnings are too small to allow saving. The second $(1-a) W$ flows into the commercial banking system, where it serves as deposits that are able to generate credit money. The bank system is able to generate more credits than the sum of the deposits, so the stream flowing into the markets has a slightly greater value, although a part of the deposits

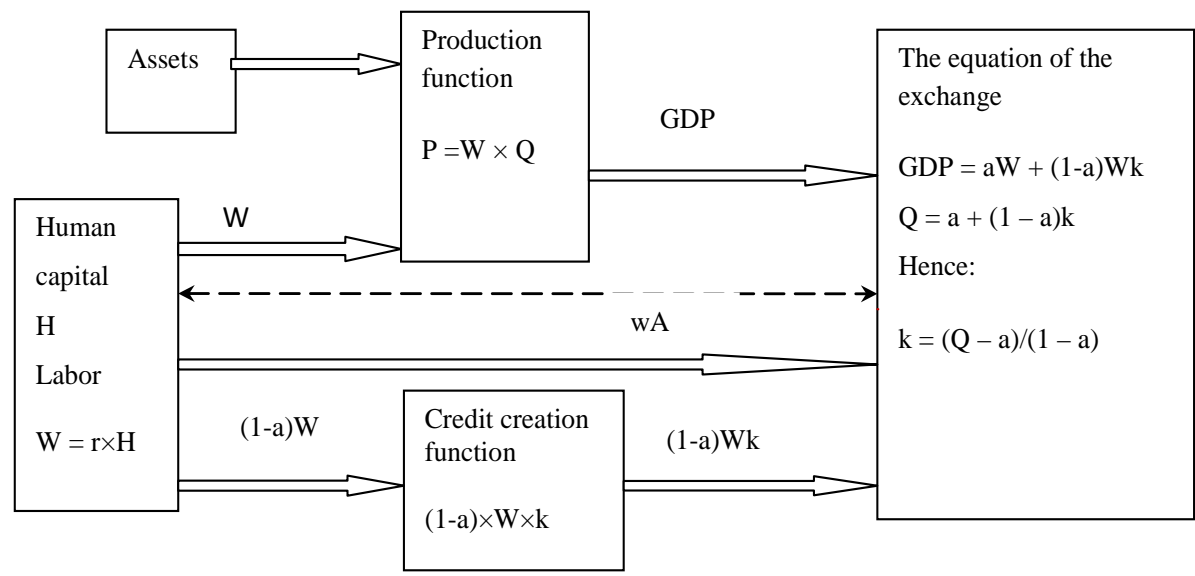

Scheme 1. The two streams of money-the goods economy and the Equation of exchange. Source: The idea of Scheme 1 comes from [11]. 
value is held as necessary reserves. These reserves assure the current liquidity of banks.

The wage Equation of the exchange equalizes GDP with the sum of money, so it may be written as follows:

$$
G D P=G D P R(1+i)=a W+(1-a) W k
$$

where: GDPR is real GDP, (i) denotes index of inflation, (a) denotes the percentage of earnings that flow directly into the market, $(\mathrm{k})$ denotes the factor that increases the initial value of deposits processed to credits. The Equation of the exchange allows to determine the $(\mathrm{k})$, which guarantees that inflation is zero.

In order to compute the $\mathrm{k}$, under condition $i=0$, Equation (10) is divided by the variable $\mathrm{W}$. Then we have Equation (11), where $Q_{r}$ denotes real labor productivity:

$$
Q=Q_{r}=a+(1-a) k
$$

Hence, this implies solution

$$
k=\left(Q_{r}-a\right) /(1-a)
$$

Thus, the stream of credit money is equal to:

$$
\text { Credit }=(1-a) W\left(Q_{r}-a\right) /(1-a)=W\left(Q_{r}-a\right)
$$

A net credit computed as credit decreased by percentage (b), where b denotes a percentage of liquidity reserves, is as follows:

$$
\text { Netcredit }=W\left(Q_{r}-a\right)-b W\left(Q_{r}-a\right)=W\left(Q_{r}-a\right)(1-b)
$$

At the end, the value of admissible credit is equal to $W\left(Q_{r}-a\right)(1-b)$. As the formulas show, the credit depends on: stream of earnings $\mathrm{W}$, real labor productivity $Q_{r}$, the level of poverty (or welfare a), and the level of required reserves for assuring liquidity (b). Thus, the more rich the country is, the more credit is permitted.

For example, for Poland, a country not rich although not very poor, net credit can be roughly estimated in line with pattern (14). The Q is close to 2.0, and GDP is close to 1500 billion zł. Thus, W is close to 750 billion zł. No more that 20 percent of earnings makes deposits admissible for credit creation $(a=0.8)$. So, assuming the liquidity reserves are level at $20 \%$, we get the estimation: $750 \times(2.0-0.8)(1-0.2)=720$ billions zł.

The labor productivity index $\mathrm{Q}$ manifests in most macroeconomic considerations. This index is pretty constant, since it is the inverse value of the labor share ratio. This means the possibilities of it increasing are remote. Instead, it declines effortlessly as a result of compensations for unproductive labor, and all increases that are enforced by different protests, no matter whether they are rightful or not. There is one main imperative in the described financial system. A country should tend to increasing the $\mathrm{Q}$ or to maintain its former value at least. The $\mathrm{Q}$ should never decline, since this means the phenomenon of inflation. This index participates in many issues, among which is the amount of compensations for the public sector.

Accepting the condition that the $\mathrm{Q}$ ought to be at least as in the former year a formula for permissible compensation for the PSE implies from the Q definition: $Q=G D P /\left(W_{1}+W_{2}\right)$, so that $W_{2}=G D P / Q-W_{1}$. Here GDP denotes the GDP planned for the considered year, and $W_{1}$ denotes compensations for the companies' employees. The above formula constructs the essential mandatory constraint in the economy, with the tax-less financing of the PSE.

\section{Making the GCA Work and Some Costs-Benefits Analysis}

The introduction of the GCA needs two stages. The first, lasting say five years, when countries implement a new financial system and are able to use the self-financing of labor for the PSE. This means the role of the central banks changes to payers and cash money emissions no longer exist. Then the countries experience many benefits such as a lack of budget deficits and the possibility of taxes declining. The second stage starts at the end of negotiations for the treaty of the world political agreement of creating the GCA i.e., relinquishing the exchange rates applied during economic exchanges. This agreement, signed by the GCA founder countries, contains the decision to introduce the one currency unit and the translation of all values to a new parity.

The remainder states have to get approval to access the GCA. Thus, one of the initial steps toward the GCE is 
determining the name of the monetary unit. A natural suggestion here is that the world could accept the name "world dollar", and the standard value would be that of the current dollar, since it is the most widespread currency around the world and has served as the main reserve currency. Due to this simple move, one dollar becomes the world unit of value.

What sort of costs and benefits appear if any country becomes a member of the GCA? It is hard to show any costs. In contrast to previous opinions, the benefits are numerous and offer great value. Despite the abolition of paper money emission by the USA, this country would gain tax-less financing of the PSE that produces billions of dollars per year-an estimated $20 \%$ of total compensations. Of course, the control of labor productivity would have to be tightened in order to have constant growth, but that would not hurt much, particularly in the case of the USA. What's more, the USA would avoid the danger that a river of dollar banknotes would fly to the source of the emission when the dollar entered a phase of contraction. This state of affairs could happen if the present dollar troubles continue.

The economic benefits are related to the common introduction of labor self-financing and the exchange rate-less economy. It changes the debt economy that presently works as engines driven by debts [22] to a normal economy, where a budget deficit is an extraordinary event that may point to bad management or enormous military expenses. The new order means lack of crises, declines in unemployment, possibilities of tax decreasing, favorable economic situations, and opportunities for constant development. Self-financing of labor absorbs all of J. M. Keynes' effects, without any undesired outcomes. Of course, good governance on each level of the economy is always a key factor of success. Labor productivity cannot turn down. In addition, maintaining a proper proportion between population and native land territory is an indispensable factor of accomplishment.

The political effects of the introduction of a GCA could be powerful. It is clear the GCA could be a powerful driver of globalization. The present views on globalization are described by many authors, of whom the best known is J. Stiglitz [1]. It is hard to add anything to this author's precise analysis, but it is essential to share his diagnosis. It is also clear that the vision of globalization created by J. Stiglitz still needs a correct solution of one essential agenda, namely the problem of the reserve money system. Neither bankor nor globol is a remedy for the reserve money system, but rather a common acceptance of the view that money arises as a consequence of labor. Assuming this scientific point of view, money is an abstract category related to capital and labor. Money is an accounting record of labor receivable.

It is about time to accept A. Smith's opinion and the earlier experiences of humanity known from Mesopotamian town-states and Egypt. Adam Smith ([23], Book I, Ch. V) wrote that “... It was not by gold or by silver, but by labor, that all the wealth of the world was originally purchased; and its value, to those who possess it, and who want to exchange it for some new production, is precisely equal to the quantity of labor which it can enable them to purchase or command...."

Regrettably, these true words have not changed economies to a natural state, where labor produces money so that labor is self-financing. Instead, producing paper money became the most beneficial occupation, so the powerful states assigned it as their royalty. Although the roots of monetarism come from coined money, economists soon accepted the theory of the monetary Equation of exchange, with all the wrong consequences. Fortunately, these questions have already been sufficiently explained [11].

Therefore, the correct solution of the reserve currency agenda would be the introduction of the GCA, which would have only one money unit, and the problem of reserve currency would no longer exist. In the GCA each member could create money by productive labor striving for the welfare state. An individual doing the same job would earn different monthly pay in dissimilar countries. In a poor country it could be, let us say, 200 WD (world dollar), in Poland it could be 750 WD, but in the USA it could reach 1500 WD. But the process of convergence is already set in motion. Each country would enjoy a better future, without the danger that the authorities would establish an exchange rate, for example "one peso for one dollar." If that happened, the so-called "monetary policy" would destroy the country's economy. China, after changing USD to WD, could purchase raw materials and goods all over the world so there would be no danger of a loss. The debt the USA owes China would be paid with WD or in clearings made in WD.

When the GCA works, then no emission of dollars exists. Such activities are forbidden and are liable to be penalized. Three problems have to be solved: (a) how to translate all values into world dollars, (b) what is the future of cash existing from past emissions?, and (c) how would an audit be organized and controlled in the new financial system? An answer to the second question is clear. Paper money belongs to the past. The future is free from coined and paper money. Therefore, the problem is how to implement a process that changes the paper 
dollars prevalent in the world to electronic accounting records?

First, if an individual owns some dollar banknotes and he/she wants to keep them, he/she can do it. But if such people changed their decision, then a commercial bank would open an account for them and the bank would destroy the paper dollars. The bank would assure easy access to clients' accounts and all facilities for easy payments. Paper dollars belonging to organizations would have the same fate. Those paid to commercial banks would be destroyed by fire and their value would appear as accounting records. This operation would be accomplished by commercial banks at the beginning in respect of the banks' cash, and later during the phase of removing the rest of the dollar banknotes.

Some doubts could appear here about possible fraud. A question arises whether a bank, while destroying cash, could add an amount over the value of the owned dollar banknotes. Fortunately, the accounting system would be sufficiently robust to prevent such a fraud. The value of cash (paper dollars) would be recorded in the bank's balance sheet. The same value would have to appear in the balance sheet at the start of the banknote-less era, after the paper dollars have been burnt. Then the possibility of the fraud would be no greater than with paper money. Nobody can add one dollar to the balance sheet, since each record would be a double entry. The features of the double-entry accounting system sufficiently defend the new system from this kind of fraud.

However, an international project like the GCA is exposed to other risks, among which is the risk of incorrectly measuring the essential variables. These are GDP, the Q index, and the upper limit of compensation for the PSE. Moreover, fraud could happen at the top level of governance through unethical activities by the central bank or country officers. To prevent both mistakes and fraud, internal and external audit systems would be necessary. International independent auditors would have to monitor the external audit.

A very responsible task for a country that decided to access the GCA would be converting compensations to world dollars. Authorities would have to recalculate wages and salaries to the new monetary unit. The most important agenda would be to establish an adequate value of minimum pay. A feature of developed countries is that the level of the legal minimum wage is consistent with an amount close to $8 \%$ of an employee's human capital (HC). This is the case in the USA in respect of the minimum wage (see Table 1), but it is not the case in Poland, for example. Poland's labor productivity index, Q, is too low. A useful function estimating the relation between the $\mathrm{Q}$ and the percentage consistency $(\mathrm{C})$ is as follows:

$$
C=56.24+85.30 \times 1 g_{10}(Q)
$$

The computations placed in the body of Table 1 concern teenagers (17 years old in the USA and 18 in Poland). The bottom part of Table 1 presents computations for a $(2+2$ person) family. It illustrates the fairness of the minimum pay level.

Some additional interpretation is needed. The first note relates to calculations for the USA. In line 9, there is 98,5\% consistency between legal and theoretical pay. In fact, many states and cities establish a higher minimum wage. In addition, the use of only one value for the cost of living for the USA raises the value of HC. The cost of living involves only the indispensable costs necessary for HC's normal growth, so these costs are slightly less than the social minimum. Therefore, it is assumed the percent of consistency is at least $100 \%$.

The second note concerns the monthly amount of pensions. Line 15 indicates that the cost of living per person in the whole period of life exceeds the indispensable, initial cost. A pension fund collected over 44 years under the condition that the capitalization rate is $3 \%$ results in an amount of $\$ 318,455$ per person. Thus, a rough estimation gives the following amounts: $\$ 318,455$ : (20 years $\times 12$ months) $=\$ 1,327$. This means that, even without interest from a still existing fund, over 20 years the pension is on the level of $96 \%$ of minimum pay assumed as the level of earning.

The second method of establishing minimum pay applies the exchange rate with the use of labor productivity parity. In the case of Poland, we see that the minimum wage computed in line with human capital theory is $2,416 \mathrm{zł}$ per month. This is equal to $13.73 \mathrm{zł}$ per hour (2,416 zł: 176 hours). Since the average value of the exchange rate depends on the parity of the labor productivity Q and according to [24], the formula is as follows:

$$
E R\left[\frac{z t}{\$}\right]=\frac{S_{p}}{S_{A}} \times \frac{Q_{A}}{Q_{P}}
$$

where $\mathrm{S}$ denotes average wages, index $\mathrm{P}$ denotes Poland, index A denotes the USA, $E R$-exchange rate. Applying this formula to minimum wages the issue is as follows: 
Table 1. Estimation of the minimum wage for the USA and Poland for 2014.

\begin{tabular}{|c|c|c|c|}
\hline & Economic variable & USA & Poland \\
\hline \multicolumn{4}{|c|}{ Computation of human capital and fair pay } \\
\hline 1 & Estimated indispensable monthly cost of living (four- or five-person family) & $\$ 475$ & $750 \mathrm{zł}$ \\
\hline 2 & Period of continuous compounding $(\mathrm{t})$ & 17 years & 18 years \\
\hline 3 & Capital $H(p)=k(\exp (p t)-1) / p, p=0.08, k=12 \times \$ 475$ & $\$ 20,6354$ & $362,328 \mathrm{zl}$ \\
\hline 4 & Yearly cost of labor $W=s \times H(p), E(s)=p$ & $\$ 16,508$ & $28,986 \mathrm{zł}$ \\
\hline 5 & Monthly cost of labor W/12 & $\$ 1376$ & $2416 \mathrm{zl}$ \\
\hline 6 & Legal minimum wage $(176$ hours $\times \$ 7.25$ ) & $\$ 1276$ & $1680 \mathrm{zl}^{*}$ \\
\hline 7 & Employer's additional payments & $6.2 \%$ & $20,74 \%$ \\
\hline 8 & Legal cost of labor & $\$ 1355$ & $2028 \mathrm{zl}$ \\
\hline 9 & Percent of consistency & $98.5 \%{ }^{*}$ & $84 \%$ \\
\hline \multicolumn{4}{|c|}{ Family revenues and pension funds } \\
\hline 10 & Family ( $2+2$ persons $)$ & & \\
\hline 11 & Earnings $(2 \times 1376$ in the USA) & $\$ 2752$ & $4832 \mathrm{zł}$ \\
\hline 12 & Assumed pension payment, $20 \%$ & 550 & 966 \\
\hline 13 & Assumed healthcare payment, $10 \%$ & 275 & 483 \\
\hline 14 & Fund for cost of living & 1926 & 3,383 \\
\hline 15 & Cost of living per person (line 14: 4) & 482 & 84,575 \\
\hline 16 & Years of capitalizing the pension fund ( $3 \%$ capitalization rate), FV—future value & 53 years & 65 years \\
\hline 17 & FV (3\%, 46 years) per person & $\$ 318,455$ & \\
\hline 18 & FV (3\%, 47 years) per person & & $581,898 \mathrm{zl}$ \\
\hline
\end{tabular}

${ }^{*}$ Consistency of the USA legal minimum pay is $100 \%$ or more, since many states and towns apply a rate more than Federal one. ${ }^{*}$ The Amount $1680 \mathrm{z}$ is determined in a legal act of the Polish Government Dz.U. z $13^{\text {th }}$ Sept. 2013 y., poz. 1074.

$$
S_{p}[\mathrm{zl}]=E R \frac{\mathrm{zl}}{\$} \times \frac{Q_{A}}{Q_{P}} \times S_{A}[\$]=3.16 \times \frac{1.953}{3.648} \times(7.25 \times 1.062)=13.02 \mathrm{zl}
$$

The value of $13.02 \mathrm{zł}$ calculated above is close to the $13.73 \mathrm{zł}$ obtained by human capital theory applications.

The presented methods are helpful for converting wages to world dollars. The simplest approach for establishing the minimum wage relies on determining the percentage of consistency with American pay. Then this percentage determines the value in world dollars. In the case of Poland, the monthly cost of labor ought to be $\$ 1.376 \times 0.84=1156 \mathrm{WD}$. The hourly wage is then $6.5 \mathrm{WD}$.

Determination of the minimum wage is a fundamental task for establishing all other compensations. While doing it, a spread between the minimum wage as discussed above and pay for an individual with the highest regular human capital should be taken into account. This Plato proportion has been known from ancient times. This spread should be about six times. Human capital computations confirm this proportion.

Eight percent of the sum of the first three elements estimates fair basic pay. The fourth element (creativity capital) is often a source of enormous earnings, as in the case of famous discoverers, artists, players, and inventors. Basic pay is determined by the formula $W=p \times(K+E+D(T))$, where $(E+D(T))$ estimates the intellectual capital. Now, let us assume that an individual completed his/her PhD study (professional education lasted 10 years). Then this person was employed by an institution up to the age of 65 years. The learning parameter is high at 0,10 . It is assumed the cost of each year of study was 24,000 USD. Then the human capital H(T) is equal to $546,568+367,662+386,162=1,300,392$ USD . Hence, the spread is estimated to be $1,300,392$ USD : 
206,354 USD $=6.3$ times . Accessing the GCE is a time zero when the new economics starts. Introducing a greater order to economic matters is essential.

\section{Some Remarks about the Paths of Economic Growth. The Case of Poland}

The GCA is a world enterprise, so it needs adequate control and clear ratios to ensure correct evaluation. The tandem of GDP and the Q are the pair that discloses the most vital information, so this pair brings essential information for a country evaluation. Therefore, the system of GDP and the Q measurement should be simple and transparent. These variables must be under the control of both country and international auditors. What is more, these measures should come from accounting integrated systems working under the tight control of auditors. This means accounting data from economic units should be processed in informatics systems yielding a correct measure of the GDP and the Q.

Therefore, it is the income approach to GDP measurement, instead of the expenditure one, that is convenient for system processing. As is commonly known, the income components include compensations, incomes of all sorts of economic units, rents, interest, sales taxes, and depreciation of assets. It should be clear that compensations and depreciations also involve the public sector. Having a system of GDP measurement working, the Q index can be easily computed from the same set of data. At present, this is tough, since the PSE are paid from taxes. Self-financing makes the process of measurement clear.

The members of the global currency area have a constant duty to strive for labor productivity growth, since this is the only correct way to progress, ensure welfare, and maintain the value of the common currency. On the other hand, the labor productivity index is a very stable measurer (it is the inverse value of labor share), so it is rather difficult to achieve and maintain real growth. Nevertheless, it is essential and possible. The function depicting economic activity [25] allows for the introduction of a model of economic activity that is helpful for examining possible paths of growth. This model arises as follows:

$$
P=W \times Q=W(1+r)\left(1+\frac{A}{H} \times \frac{Z}{u}\right) \cong W \exp \frac{A \times F}{W}
$$

where: $P$-denotes output, $r$ —denotes cost profitability, $A$-is the value of assets, $H$-denotes human capital of employees, $z$ - turnover ratio, and $u$-denotes percentage of compensation $(W=u H)$. The model (right side of Equation (16)) is derived from the function of economic activity. The variable $\mathrm{F}$ denotes level of management and synthesizes all influences beyond $A$ and $W$. Let us note that the $Q=\exp [A F / W]$ and there is a tight relationship between the $Q$ and the $F$.

Model (16) shows that each set of variables $\mathrm{P}, \mathrm{A}$, and $\mathrm{F}$ determines the relevant value of $\mathrm{W}$. Therefore, assuming the variable $\mathrm{F}$ should not decline or should grow slightly, one can use this model to analyze possible paths of growth. In order to find the $\mathrm{W}$, we reshape model (16) to the form:

$$
W=P \exp \left[-\frac{A F}{W}\right] \text { or } W=\varphi(W)
$$

To find the solution of Equation (18) for the $\mathrm{W}$ we use the fixed-point theorem proved by S. Banach. What is more, $\mathrm{S}$. Banach introduced a constructive algorithm for finding a solution under the condition that mapping $\varphi$ is a contraction [26].

Theorem (S. Banach). Let (X; d) be a complete metric space and $f: X X$ be a map such that $d\left(f(x), f\left(x^{\prime}\right)\right) \leq c d(x$, $\left.x^{\prime}\right)$ for some $0 \leq c<1$ and all $x$ and $x^{\prime}$ in $X$. Then $f$ has $a$ unique fixed point in $X$. Moreover, for any $x 0 e X$ the sequence of iterates $x 0 ; f(x 0) ; f(f(x 0)) ;::$ : converges to the fixed point $f$.

To apply this theorem, we do not need to check the assumption whether $\varphi$ is a contraction. If not, the iteration process is divergent. Let us set in motion the iteration process with an initial value of $W=600, P=1530$, and $A=2490$ that roughly express data of the Polish economy. We assume the value of $F=0.220$. The values of $W, P$, and $A$ are in billions of the Polish monetary unit zt. Then the iteration sequence leads to the value of $W$ : $600,614,626,638, \cdots, 697,697,697$, and then the $Q=2.19$. W is determined; however, the $Q$ is too high, since this value was slightly less than 2,0 in 2013 . Decreasing the $F$ to value 0.212 , we get another solution for W: 600, 634, 666, 692, 713, $\cdots, 772,772,772$, and the $Q=1.980$ is better fitted. The model is ready for use for searching a path of the $Q$ growth in year 2014 and further. The problem is how to attain the $Q$ close to 3.0 since Western European countries, originators of the euro currency area, have this value greater than 3.0. 
Table 2 consists of results of simulations i.e., searching such value of $\mathrm{W}$ that the $\mathrm{Q}$ grows the most. The left side of the table is filled with numbers that represent a rather easy path, but not in a time of crisis. GDP and assets growth are assumed to be $3 \%$ and $2 \%$, respectively. Numerous values of the variable $\mathrm{F}$ set the simulation in motion. It increases to the point where the $\mathrm{Q}$ grows and the iteration process is convergent determining the relevant W. The path (I) is rather successful. The Polish economy may follow this path, yet the growth of the Q is slow. In the year 2023 the $Q=2.12$; it is still a long distance from the from the $\mathrm{Q}$ of Western countries. With this small Q Poland does not fit into the euro currency area (lack of labor productivity parity) but it could be a good member of the GCE, since the Q is still growing. Such a country does not contribute to inflation. Compensations are lower because the country is poorer.

The right side presents a steep path of growth, where it is assumed that GDP and assets grow 7\% and 3\%, respectively. Striving for the maximum rise of the Q, W has to be limited. Therefore, during 2018 an event happens so that the $\mathrm{Q}$ no longer grows. It is a situation of too low demand that does not allow for growth to maintain the high cost of profitability and high turnover. Too low compensations through five years have caused that growth of labor productivity to be restrained. From a social point of view, this situation shows a crisis and protests. This path no longer goes smoothly. Only a high rise of compensations allows the continuation of this path of growth, so the end result is poor.

There is still a third way to strive for labor productivity. This is a program of real reforms that limits the denominator of the Q. First of all, it is good management and control of compensations, and their consistency with the human capital of all employees. Then a wise reform of the public sector is necessary. Poland passed a spectacular system change in 1989, and in spite of it, this sector still grows. After 25 years, employment in the public sector has grown more than three times. To be a member of the GCA requires firm control of labor productivity.

\section{Concluding Remarks}

Globalization is a vital process for world progress in both economic and political dimensions. It is evident that global economics requires a correct theory, and here is the problem. As J. Stiglitz's [4] analysis shows, at the beginning of the nineties globalization was welcomed with the hope of progress and a better future, but less than two decades later, serious protests have appeared. Presently, globalization is often connected with dark forces. The global economy needs a strong, correct theory, and honest political willpower. These attributes cannot be replaced by military force and political domination. Flaws of economics and, in particular, an inadequate theory of money, are well known and hotly debated by many authors [2] [27]. Regardless of this confusing situation, the

Table 2. Simulation of paths of growth for the Polish economy.

\begin{tabular}{|c|c|c|c|c|c|c|c|c|c|c|c|}
\hline Year & $\mathrm{P}$ & A & F & $\mathrm{W}$ & $\mathrm{Q}$ & Rok & $\mathrm{P}$ & A & $\mathrm{F}$ & $\mathrm{W}$ & $\mathrm{Q}$ \\
\hline \multicolumn{6}{|c|}{ Path I (easy) } & \multicolumn{6}{|c|}{ Path II (steep) } \\
\hline & $+3 \%$ & $+2 \%$ & & & & & $+7 \%$ & $+3 \%$ & & & \\
\hline 13 & 1530 & 2490 & 0.212 & 738.7 & 1.980 & 13 & 1530 & 2490 & 0.212 & 738.7 & 1.980 \\
\hline 14 & 1576 & 2540 & 0.217 & 771.2 & 2.044 & 14 & 1637 & 2565 & 0.223 & 802.8 & 2.038 \\
\hline 15 & 1623 & 2591 & 0.220 & 785.0 & 2.066 & 15 & 1752 & 2642 & 0.234 & 837.2 & 2.093 \\
\hline 16 & 1672 & 2643 & 0.223 & 801.3 & 2.087 & 16 & 1874 & 2721 & 0.245 & 873.7 & 2.145 \\
\hline 17 & 1722 & 2696 & 0.226 & 816.4 & 2.109 & 17 & 2005 & 2803 & 0.256 & 913.6 & 2.196 \\
\hline 18 & 1774 & 2750 & 0.225 & 820.1 & 2.127 & 18 & 2146 & 2887 & $0.26(5)$ & 982.6 & 2.195 \\
\hline 19 & 1827 & 2805 & 0.232 & 848.3 & 2.154 & \multicolumn{6}{|c|}{ The growth of the $Q$ is blocked } \\
\hline 20 & 1882 & 2861 & 0.235 & 864.8 & 2.177 & 19 & 2296 & 2974 & 0.270 & 1121.5 & 2.049 \\
\hline 21 & 1939 & 2918 & 0.238 & 882.0 & 2.199 & 20 & 2460 & 3063 & 0.2763 & 1242.3 & 1.986 \\
\hline 22 & 1997 & 2976 & 0.240 & 912.6 & 2.189 & 21 & 2629 & 3155 & $0.280(6)$ & 1258.5 & 2.186 \\
\hline 23 & 2056 & 3036 & 0.2425 & 930.2 & 2.212 & 22 & 2813 & 3249 & $0.28533(2)$ & 1342.8 & 2.244 \\
\hline
\end{tabular}


monetarists still maintain that money is simply a product and then they manufacture cash money from nothing, contaminating natural flows of capital and value in economies. They do not bother with contradictions.

The money-goods economy is a great achievement on condition that the triad: capital-labor-money is completely recognized and respected. Then human capital becomes a means of increasing value; that is to say, for creating well-being. Since then human capital develops in a family unit, that's where the economics starts. Therefore, the family sector is an essential part of the economy and has serious responsibility, comparable to that assigned to other sectors. The management of the family is where human capital grows and where household budgeting and control are vital qualities of modern society. Nonetheless, a correct valuation of human capital and attention to fairness of compensation is the responsibility of country authorities.

The integrative currency area concept yields insight into the duality of capital and labor. It reveals the self-financing of labor and brings to light new possibilities of a money-goods economy. An economy without a budget deficit and with little tax is a real perspective. But the integrative currency area leads in the final effect to a global currency area; that is to say, to a world with new qualities and a greater hope that globalization will lead to peaceful coexistence and balanced development. In this project, the future world is without a reserve currency system. J. Stiglitz and B. Greenwald [28] end their precise analysis conducted in the old financial framework with an opinion that " $\ldots$ a new global reserve system is absolutely essential, if we are to restore the global economy to sustained prosperity and stability. But achieving this, too, will not be easy ...” In a world with merely one currency, a government will likely hold surplus money in a portfolio of bonds of different countries, taking care of liquidity and gaining additional earnings.

\section{References}

[1] Stiglitz, J. (2007) Making Globalization Work. Polish Edition, Polish Scientific Publishers PWN, Warsaw.

[2] Dobija, M. and Kurek, B. (2013) Towards Scientific Economics. Modern Economy, 4, 293-304. http://dx.doi.org/10.4236/me.2013.44033

[3] Dobija, M. and Kurek, B. (2013) Scientific Provenance of Accounting. International Journal of Accounting and Economics Studies, 1, 16-24. http://dx.doi.org/10.14419/ijaes.v1i2.1054

[4] Stiglitz, J. (2006) The Roaring Nineties. A New History of the World's Most Prosperous Decade. Polish Edition, Polish Scientific Publishers PWN, Warsaw.

[5] Dobija, M. (2013) The Theoretical Basis of an Integrative Currency Area. The Dilemmas of Polish Accession to the Euro Zone. Management and Business Administration. Central Europe, 21, 3-23.

[6] Dobija, M. (2014) Formation of the Integrative Currency Area. SOP Transactions on Economic Research, 1, 1-9.

[7] Pacioli, L. (1494) Summa de Arithmetica. Geometria, Proportioni et Proportionalita, Venice.

[8] Bliss, Ch. (1975) Capital Theory and the Distribution of Income. North-Holland Publishing, Oxford.

[9] Cohen Avi, J. and Harcourt, G.C. (2003) Retrospectives, Whatever Happened to the Cambridge Capital Theory Controversies? Journal of Economic Perspectives, 17, 199-214. http://dx.doi.org/10.1257/089533003321165010

[10] Solow, R. (1963) Capital Theory and the Rate of Return. North-Holland Publishing Company, Amsterdam.

[11] Dobija, M. (2011) Abstract Nature of Money and the Modern Equation of Exchange. Modern Economy, 2, $142-152$. http://dx.doi.org/10.4236/me.2011.22019

[12] Kurek, B. (2012) An Estimation of the Capital Growth Rate in Business Activities. Modern Economy, 3, 364-372. http://dx.doi.org/10.4236/me.2012.34047

[13] Atkins, P. (2007) Four Laws That Drive the Universe. Oxford University Press, New York.

[14] Dobija, M. (2007) Abstract Nature of Capital and Money. In: Cornwall, L.M., Ed., New Developments in Banking and Finance, Nova Science Publishers Inc., New York, 89-114.

[15] Gleiser, M. (2006) Can Science Explain Itself? In: Brockman, J., Ed., What Is Your Dangerous Idea, Edge Foundation, 128-130. (Polish Edition: “Niebezpieczne idee we współczesnej nauce”, Smak Słowa, Sopot, 2008)

[16] Barrow, J.D. (2002) The Constant of Nature: From Alpha to Omega. Jonathan Cape, London.

[17] Kurek, B. (2011) A Hypothesis of the Deterministic Risk Premium. Wydawnictwo Uniwersytetu Ekonomicznego w Krakowie, Kraków.

[18] Struve, V. (1969) Some New Data on the Organization of Labor and on Social Structure in Sumer During the Reign of the IIIrd Dynasty of Ur. In: Diakonoff, I.M., Ed., Ancient Mesopotamia, Nauka, Moscow, 128-129.

[19] Schmandt-Besserat, D. (2007) When Writing Met Art. From Symbol to Story. University of Texas Press, Austin. 
[20] Dobija, M. (2011) Labour Productivity vs. Minimum Wage Level. Modern Economy, 2, 780-787. http://dx.doi.org/10.4236/me.2011.25086

[21] Kozioł, W. (2007) Wykorzystanie Analitycznej Funkcji Produkcji w Procesie Motywacji Płacowej (Production Function in Shaping of Compensations). Zeszyty Naukowe UEK, 752, 125-136.

[22] Rushkoff, D. (2006) Open Source Currency. In: Brockman, J., Ed., What Is Your Dangerous Idea, Edge Foundation, 244-245. (Polish Edition: "Niebezpieczne idee we współczesnej nauce”, Smak Słowa, Sopot 2008)

[23] Smith, A. (1776) An Inquiry into the Nature and Causes of the Wealth of Nations. http://www.econlib.org/library/Smith/smWN2.html

[24] Jedrzejczyk, M. (2012) Labor Productivity Parity vs. Trend of Exchange Rate. Modern Economy, 3, 780-785. http://dx.doi.org/10.4236/me.2012.36099

[25] Dobija, M. (2012) Political Reform Based on a Human Capital Research Program. Argumenta Oeconomica Cracoviensia, 8, 9-29.

[26] Conrad, K. (2014) The Contraction Mapping Theorem. http://www.math.uconn.edu/ kconrad/blurbs/analysis/contraction.pdf

[27] Davar, E. (2011) Flaws of Modern Economic Theory: The Origins of the Contemporary Financial-Economic Crisis, Modern Economy, 2, 25-30. http://dx.doi.org/10.4236/me.2011.21004

[28] Stiglitz, J. and Greenwald, B. (2010) Towards a New Global Reserve System. Journal of Globalization and Development, 1. http://www.bepress.com/jgd/vol1/iss2/art10 